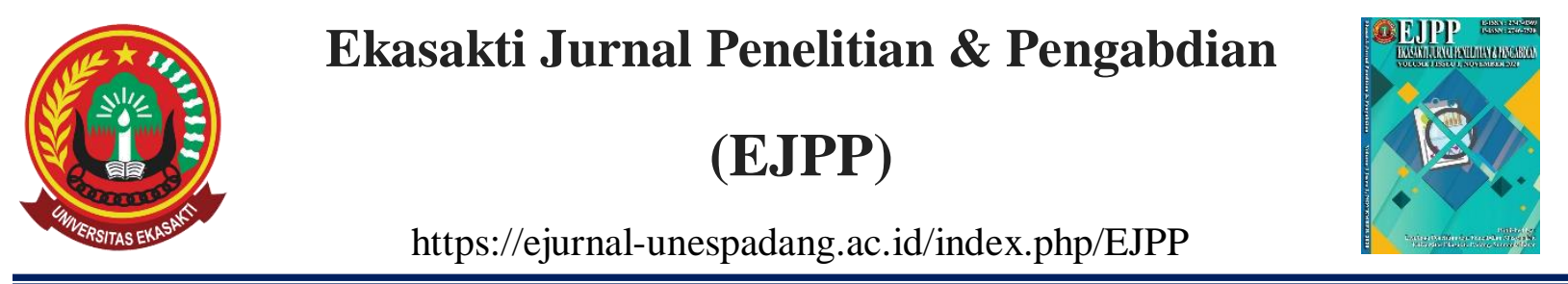

\title{
PERSEPSI MAHASISWA PROGRAM STUDI PENDIDIKAN MATEMATIKA TERHADAP PEMBELAJARAN DARING PADA MASA COVID-19
}

\author{
Rosmiyati $^{1}$, dan Roza Zaimil $^{2}$ \\ ${ }^{1)}$ Universitas Mahaputra Muhammad Yamin \\ Email: rosmiyati.rosmiyati123@gmail.com \\ ${ }^{2)}$ Universitas Mahaputra Muhammad Yamin \\ Email: rozazaimil1406@gmail.com
}

\section{INFO ARTIKEL}

Received : 28/10/2021

Revised : :15/11/2021

Publish : :16/11/2021

Kata Kunci:

Covid-19, Mahasiswa, Pembelajaran Daring, Persepsi.

\begin{abstract}
ABSTRAK
Penelitian ini dilatarbelakangi oleh wabah covid-19 membuat proses pembelajaran berubah. Pemerintah mengeluarkan kebijakan proses pembelajaran dilakukan dari rumah untuk mengantisipasi penularan virus covid-19. Program studi Pendidikan Matematika Universitas Mahaputra Muhammad Yamin yang sebelumnya melakukan perkuliahan dengan tatap muka beralih ke pembelajaran jarak jauh atau daring. Pembelajaran daring menuntut kecakapan dosen dalam menggunakan dan mengembangkan aplikasi sebagai media pembelajaran yang menyenangkan bagi mahasiswa. Rumusan masalah dari penelitian ini adalah bagaimana persepsi mahasiswa prodi pendidikan matematika terhadap pembelajaran daring pada masa pandemi covid-19. Tujuan dari penelitian ini adalah untuk mengetahui bagaimana persepsi mahasiswa prodi pendidikan matematika terhadap pembelajaran daring pada masa pandemi covid-19. Penelitian menggunakan pendekatan kuantitatif dengan metode deskriptif. Popolasi dalam penelitian ini adalah semua mahasiswa aktif program studi pendidikan matematika yang terdaftar pada semester genap 2020/2021 yang berjumlah 36 orang. Teknik pengambilan sampel dilakukan dengan total sampling. Teknik pengumpulan data dilakukan dengan angket tertutup dengan pilihan jawaban yang sudah disediakan dan angket terbuka. Teknik analisis data yang digunakan adalah teknik analisis deskriptif kualitatif. Hasil penelitian menunjukkan 1) Indikator materi perkuliahan rata-rata 3,42 dengan persentse $85,5 \%$ berada pada kriteria sangat baik; 2) Indikator penyampaian materi rata-rata 3,11 dengan persentse 77,75\% berada pada kriteria baik; 3) Indikator pengelolaan kelas rata-rata 3,18 dengan persentse $79,5 \%$ berada pada kriteria baik; 4) Indikator evaluasi pengajaran rata-rata 2,89 dengan persentse $75,75 \%$ berada pada kriteria baik. Analisis angket terbuka menunjukkan bahwa kesulitan mahasiswa dalam pembelajaran daring diantaranya koneksi internet yang masih kurang stabil, jaringan yang sulit di daerah perdesaan tempat mereka tinggal, terbatasnya kuota internet, kurang kefokusan mahasiswa dalam belajar daring karenaperkuliahan dilakukan bersamaan dengan pekerjaan rumah. Sementara itu kelebihan pembelajaran daring adalah bisa menggunakan berbagai media pembelajaran,
\end{abstract}


pembelajaran dapat dilaksanakan dimana saja, tidak mengeluarkan biaya untuk pergi ke kampus, memudahkan mahasiswa dalam menyerahkan tugas, pembelajaran dapat melatih keahlian dibidang teknologi sehingga mahasiswa dituntut untuk lebih kreatif.

Keywords: Covid-19, Students, Online Learning, Perception.

\section{ABSTRACT}

This research was motivated by the Covid-19 outbreak, which changed the learning process. The government has issued a policy for the learning process to be carried out from home to anticipate the transmission of the Covid-19 virus. The Mathematics Education major at Mahaputra Muhammad Yamin University, which previously conducted face-to-face lectures, switched to distance or online learning. Online learning requires lecturers' skills in using and developing applications as a fun learning media for students. The problem formulation of this research is how the perception of Mathematics Education students towards online learning during the Covid-19 pandemic. The purpose of this reserach is to find out how Mathematics Education students' perception towards online during the Covid-19 pandemic. The research applies a quantitative approach with descriptive methods. The population in this study were all active students of the Mathematics Education major who are registered in the even semester of 2020/2021, totaling 36 people. The sampling technique was carried out by total sampling. The data collection technique was carried out with a closed questionnaire with answer choices that had been provided and an open questionnaire. The data analysis technique used is a qualitative descriptive analysis technique. The result of the study shows 1) The average lecture material indicator is 3.42 with a percentage of $85.5 \%$ being in very good criteria; 2) The average material delivery indicator is 3.11 with a percentage of $77.75 \%$ being in good criteria; 3) The average class management indicator is 3.18 with a percentage of $79.5 \%$ being in good criteria; 4) The average teaching evaluation indicator is 2.89 with a percentage of $75.75 \%$ being in good criteria. An open questionnaire analysis shows that students' difficulties in online learning include internet connections that are still less stable, difficult networks in rural areas where they live, limited internet quotas, lack of students focus in online learning because lectures are carried out simultaneously with homework. Meanwhile, the advantages of online learning are; the ability to use a variety of learning media, learning can be carried out anywhere, not spending money to go to campus, making it easier for students to submit assignments, learning can increace students' practice skills in the field of technology so that students are required to be more creative.

\section{DOI: https://doi.org/10.31933/ejpp.v2i1.424}

\section{PENDAHULUAN}

Belajar merupakan suatu kebutuhan bagi semua manusia. Dengan belajar seseorang dapat melakukan sesuatu yang tidak dapat dilakukan sebelumnya karena belajar merupakan proses perubahan tingkah laku atau kecakapan bagi manusia. Wabah covid-19 membuat proses pembelajaran berubah. Pemerintah mengeluarkan kebijakan proses pembelajaran dilakukan dari rumah untuk mengantisipasi penularan virus covid-19. Berebapa perguruan tinggi yang sebelumnya melakukan perkuliahan dengan tatap muka beralih ke pembelajaran jarak jauh atau daring. Begitu juga pada universitas mahaputra muhammad yamin, pembelajaran dilakukan dengan online atau daring. Pembelajaran daring akan membantu mahasiswa membentuk 
kemandirian belajar dan juga mendorong interaksi antar mahasiswa. Pembelajaran daring menuntut kecakapan dosen dalam menggunakan dan mengembangkan aplikasi sebagai media pembelajaran yang menyenangkan bagi mahasiswa.

Program studi pendidikan matematika merupakan program studi di bawah fakultas keguruan dan ilmu pendidikan. Cakupan mata kuliah pada program studi pendidikan matematika membutuhkan analisis dan pemahaman yang mendalam bagi mahasiswa. Pembelajaran daring yang tidak teraplikasi dengan media yang baik akan menjadikan proses pembelajaran yang tidak menyenangkan bagi mahasiswa. Mahasiswa akan merasa kesulitan dalam memahami setiap materi yang diberikan. Oleh sebab itu pembelajaran daring diharapkan memberikan suatu penyegaran baru bagi dosen dan mahasiswa tentang penting pemanfaatan teknologi dalam proses pembelajaran.

Berdasarkan pemikiran dari uraian tersebut, maka perlu dilakukan sebuah penelitian untuk melihat gambaran persepsi mahasiswa dengan judul "Persepsi mahasiswa program studipendidikan matematika terhadap pembelajaran daring pada masa covid-19". rumusan masalah dari penelitian ini adalah bagaimana persepsi mahasiswa prodi pendidikan matematika terhadap pembelajaran daring pada masa pandemi covid-19. Tujuan dari penelitian ini adalah untuk mengetahui bagaimana persepsi mahasiswa prodi pendidikan matematika terhadap pembelajaran daring pada masa pandemi covid-19.

\section{METODE PENELITIAN}

Penelitian menggunakan pendekatan kuantitatif dengan metode deskriptif. Menurut Trianto (2011:174), Pendekatan kuantitatif bertujuan untuk memahami fenomena tentang apa yang dialami oleh subyek penelitian yaitu memperoleh gambaran tentang persepsi mahasiswa program studi Pendidikan Matematika terhadap proses pembelajaran daring pada masa covid-19. Penggunaan metode deskriptif dalam penelitian bertujuan untuk menggambarkan secara jelas tentang persepsi mahasiswa program studi Pendidikan Matematika terhadap proses pembelajaran daring pada masa covid-19.

Penelitian dilakukan pada semester genap tahun akademik 2020/2021. Penelitian dilakukan di Universitas Mahaputra Muhammad Yamin Solok pada Program Studi Pendidikan Matematika yang terdaftar aktif di semester genap tahun akademik 2020/2021. Popolasi dalam penelitian ini adalah semua mahasiswa aktif program studi pendidikan matematika yang terdaftar pada semester genap 2020/2021 yang berjumlah 36 orang. Sampel adalah Pengambilan sampel pada penelitian ini dilakukan dengan teknik Cluster random sampling dimana teknik ini memberikan peluang yang sama bagi setiap unsur (anggota) populasi untuk dipilih menjadi anggota sampel. Sampel dalam penelitian ini dilakukan dengan total sampling.

Teknik pengumpulan data dalam penelitian ini dilakukan dengan angket. Jenis angket yang digunakan adalah angket tertutup dengan pilihan jawaban yang sudah disediakan dan angket terbuka. Angket yang digunakan untuk mengetahui persepsi mahasiswa program studi pendidikan matematika terhadap pembelajaran daring pada masa covid-19. Teknik analisis data 
yang digunakan adalah teknik analisis deskriptif kualitatif. Skor data hasil angket menggunakan pengukuran Skala likert. Dengan kategori bobot penilaian berikut.

Tabel 1. Bobot Penilaian Skala Likert dalam Trianto (2010:245)

\begin{tabular}{lccc}
\hline \multicolumn{1}{c}{ Pilihan Jawaban } & Kode & \multicolumn{2}{c}{ Skor } \\
\cline { 3 - 4 } Sangat setuju & SS & 4 & 1 \\
Setuju & S & 3 & 2 \\
Tidak setuju & TS & 2 & 3 \\
Sangat Tidak Setuju & STS & 1 & 4 \\
\hline
\end{tabular}

Skor data hasil angket dihitung dengan rumus persentase sebagai berikut (Kamelta, 2013:144):

$$
P=\frac{F}{N} \times 100 \%
$$

Keterangan

$\mathrm{P}=$ Nilai persentase jawaban responden

$\mathrm{F}=$ Frekuensi jawaban responden

$\mathrm{N}=$ Jumlah Responden

Jumlah persentase angket dinyatakan ke dalam kategori hasil penilaian. Penentuan kategori persentase rata-rata kualitatif menggunakan indikator berada pada Tabel berikut.

Tabel 2. Kategori Penilaian Angket, Arikunto (2010:246)

\begin{tabular}{ll}
\hline \multicolumn{1}{c}{ Interval Persentase } & \multicolumn{1}{c}{ Kategori } \\
\hline $86 \%-100 \%$ & Sangat Baik \\
$70 \%-85 \%$ & Baik \\
$54 \%-69 \%$ & Kurang Baik \\
$38 \%-53 \%$ & Tidak Baik \\
\hline
\end{tabular}

\section{HASIL DAN PEMBAHASAN}

Berdasarkan angket yang diberikan kepada mahasiswa program studi pendidikan matematika melalui google form diperoleh data persepsi mahasiswa terhadap pembelajaran daring pada Tabel 3 berikut.

Tabel 3. Media yang Efektif digunakan pada Pembelajaran Daring

\begin{tabular}{lc}
\hline Media yang Efektif & Persentase (\%) \\
\hline Video Conference Zoom & 36,1 \\
WA Group & 36,1 \\
Google Classroom & 25 \\
Webex & 0 \\
Google Meeting & 2 \\
\hline
\end{tabular}


Hasil analisis dari indikator persepsi dapat dilihat pada Tabel 4 berikut.

Tabel 4. Persepsi Mahasiswa terhadap Pembelajaran Daring

\begin{tabular}{|c|c|c|c|c|}
\hline NO & PERNYATAAN & Rata-Rata & Persentase & Kriteria \\
\hline \multirow[t]{5}{*}{1} & Materi Perkuliahan & 3,42 & $\mathbf{8 5 , 5}$ & Sangat Baik \\
\hline & $\begin{array}{l}\text { a. Dosen memberikan RPS diawal perkuliahan } \\
\text { daring }\end{array}$ & 3,55 & 88,75 & Sangat Baik \\
\hline & $\begin{array}{l}\text { b. Dosen memberikan tujuan dan arahan } \\
\text { pembelajaran yang jelas sebelum pembelajaran } \\
\text { daring dimulai }\end{array}$ & 3,47 & 86,75 & Sangat Baik \\
\hline & $\begin{array}{l}\text { c. Dosen menyediakan materi secara baik secara } \\
\text { daring sehingga membuat mudah dimengerti }\end{array}$ & 3,36 & 84 & Baik \\
\hline & $\begin{array}{l}\text { d. Dosen memberikan tugas yang relevan dengan } \\
\text { materi ajar dan tujuan pembelajaran pada } \\
\text { pembelajaran daring }\end{array}$ & 3,28 & 82 & Baik \\
\hline \multirow[t]{5}{*}{2} & Penyampaian Materi & 3,11 & $\mathbf{7 7 , 7 5}$ & Baik \\
\hline & $\begin{array}{l}\text { a. Dosen selalu memberikan penjelasan mengenai } \\
\text { materi perkuliahan ketika belajar secara daring }\end{array}$ & 3,42 & 85,5 & Sangat Baik \\
\hline & $\begin{array}{l}\text { b. Perkuliahan dengan daring memudahkan dalam } \\
\text { memahami materi perkuliahan }\end{array}$ & 2,52 & 63 & Kurang Baik \\
\hline & $\begin{array}{l}\text { c. Dosen menjelaskan pertanyaan yang diajukan } \\
\text { oleh mahasiswa ketika belajar secara daring }\end{array}$ & 3,17 & 79,25 & Baik \\
\hline & $\begin{array}{l}\text { d. Dosen mendorong mahasiswa untuk aktif di kelas } \\
\text { (contoh: bertanya, diskusi) secara daring }\end{array}$ & 3,33 & 83,25 & Baik \\
\hline \multirow[t]{5}{*}{3} & Pengelolaan Kelas & 3,18 & $\mathbf{7 9 , 5}$ & Baik \\
\hline & $\begin{array}{l}\text { a. Perkuliahan secara daring dilaksanakan tepat } \\
\text { waktu }\end{array}$ & 3,08 & 77 & Baik \\
\hline & $\begin{array}{l}\text { b. Dosen selalu membimbing dalam perkuliahan } \\
\text { dengan metode daring sehingga membuat lebih } \\
\text { paham terhadap materi perkuliahan }\end{array}$ & 3,17 & 79,25 & Baik \\
\hline & $\begin{array}{l}\text { c. Sikap dosen yang terbuka terhadap } \\
\text { masukan/kritikan untuk memperbaiki mutu } \\
\text { pembelajaran daring }\end{array}$ & 3,22 & 80,5 & Baik \\
\hline & $\begin{array}{l}\text { d. Dosen membantu kesulitan mahasiswa dalam } \\
\text { materi ajar yang dipelajari }\end{array}$ & 3,25 & 81,25 & Baik \\
\hline \multirow[t]{6}{*}{4} & Evaluasi Pengajaran & 2,89 & 72,25 & Baik \\
\hline & $\begin{array}{l}\text { a. Pembelajaran daring sangat membantu dalam } \\
\text { menggantikan pembelajaran secara tatap muka di } \\
\text { masa pandemi covid } 19\end{array}$ & 2,97 & 74,25 & Baik \\
\hline & $\begin{array}{l}\text { b. Perkuliahan dengan daring solusi belajar untuk } \\
\text { menggantikan perkuliahan tatap muka }\end{array}$ & 3,03 & 75,75 & Baik \\
\hline & $\begin{array}{l}\text { c. Pembelajaran dengan daring dapat dengan mudah } \\
\text { diakses dimana saja }\end{array}$ & 2,81 & 70,25 & Baik \\
\hline & $\begin{array}{l}\text { d. Perkuliahan dengan daring dapat mempermudah } \\
\text { dalam mengirim tugas tepat waktu }\end{array}$ & 2,75 & 68,75 & Kurang Baik \\
\hline & Jumlah & & 78,75 & Baik \\
\hline
\end{tabular}


Pembelajaran daring atau online merupakan salah satu solusi yang diberikan kepada program studi pendidikan matematika FKIP UMMY Solok di masa pandemi covid-19. Pembelajaran daring banyak mendatangkan polemik bagi mahasiswa dalam berbagai hal. Setelah ditinjau dengan pemberian angket kepada mahasiswa didapatkan informasi sebagai berikut.

1. Media yang digunakan dosen pada pembelajaran daring diantaranya adalah Video Conference Zoom, WA Group, Google Classroom, Webex dan Google Meeting. Media yang dinilai efektif bagi mahasiswa dalam pembelajaran daring digambarkan pada diagram 1 berikut.

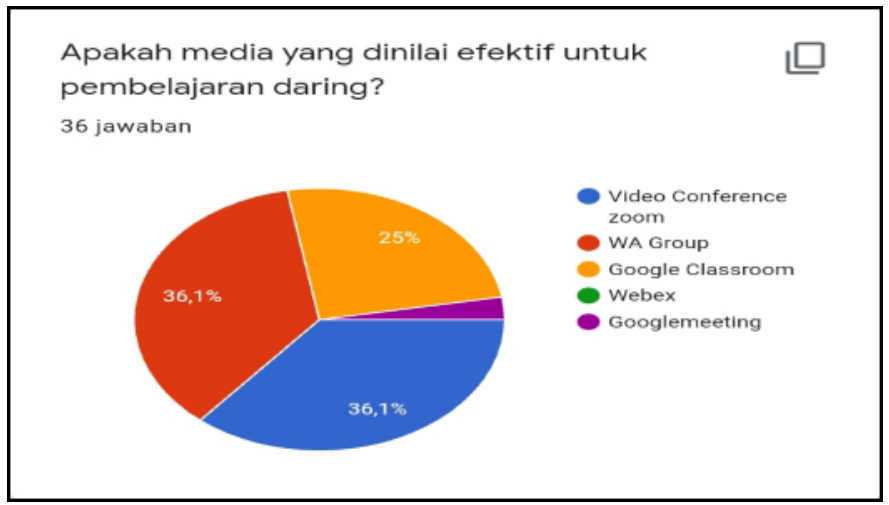

\section{Gambar 1. Media yang dinilai Efektif bagi Mahasiswa dalam Pembelajaran Daring}

Berdasarkan gambar 1 terlihat bahwa media yang dinilai efektif bagi mahasiswa dalam pembelajaran daring adalah Video Conference Zoom, WA Group dengan persentase 36,1\%. Sedangkan persentase Google Classroom 25\%, dan Google Meeting 2\%. Sementara itu Webex persentasenya $0 \%$ artinya tidak ada mahasiswa yang menilai efektif terhadap penggunaan media tersebut dalam pembelajaran.

2. Persepsi Mahasiswa terhadap Pembelajaran Daring

Berdasarkan hasil analisis angket dapat dilihat bahwa pembelajaran daring memberikan cerita baru dalam proses perkuliahan. Diantaranya dapat dilihat sebagai berikut.

a. Aspek Materi Perkuliahan

Pada aspek materi perkuliahan terlihat rata-rata persentase 85,55 dengan arti bahwa proses pembelajaran daring memberikan persentase yang sangat baik. Hal ini tergambar dari Dosen memberikan RPS diawal perkuliahan daring. Persentase berada pada kriteria sangat baik yaitu dengan rata-rata persentase $88,75 \%$. Seperti terlihat pada diagram Gambar 2, hal ini dapat diartikan bahwa dosen memberikan RPS diawal perkuliahan daring berada pada persentase baik $44,4 \%$ dan sangat baik 55,6\%. Sehingga rata-rata persentase dosen memberikan RPS diawal perkuliahan daring $85,55 \%$ berada pada kriteria sangat baik. 


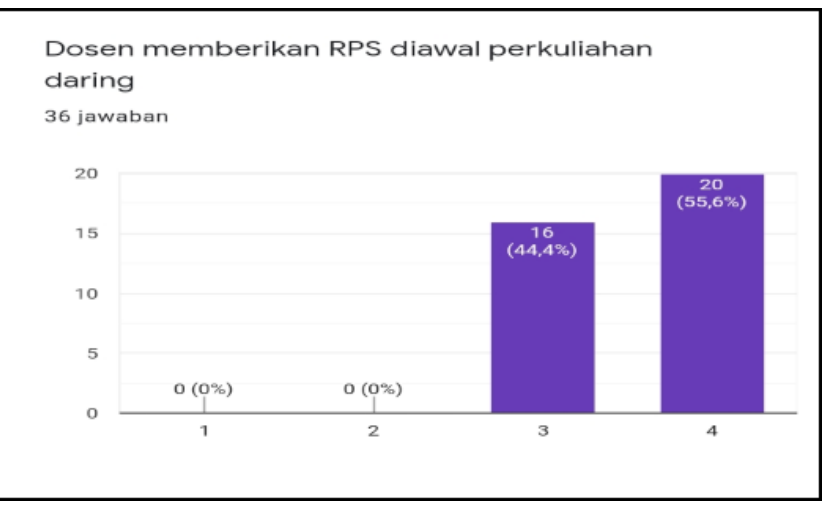

Gambar 2. Dosen Memberikan RPS diawal Perkuliahan Daring

Dosen memberikan tujuan dan arahan pembelajaran yang jelas sebelum pembelajaran daring dimulai berada pada kriteria sangat baik yaitu 86,75\%. Dengan hasil analisisnya terlihat pada Gambar 3 berikut.

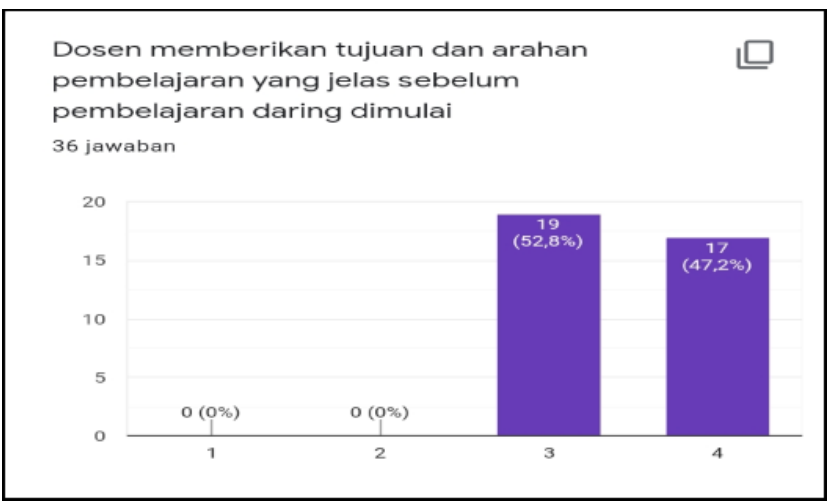

Gambar 3. Dosen memberikan tujuan dan arahan pembelajaran yang jelas sebelum pembelajaran daring

Berdasarkan Gambar 3. Terlihat bahwa Dosen memberikan tujuan dan arahan pembelajaran yang jelas sebelum pembelajaran daring $52,8 \%$ berada pada kriteria baik dan 47,2 \% berada pada kriteria sangat baik. Jadi dapat disimpulkan bahwa Dosen memberikan tujuan dan arahan pembelajaran yang jelas sebelum pembelajaran daring rata-rata $86,75 \%$ berada pada kriteria sangat baik.

Dosen menyediakan materi secara baik secara daring sehingga membuat mudah dimengerti terlihat pada Gambar 4 di bawah. Berdasarkan Gambar 4 tersebut terlihat bahwa Dosen menyediakan materi secara baik secara daring sehingga membuat mudah dimengerti berada pada kriteria baik 63,9\% dan kriteria sangat baik 36,1\%. Sehingga dapat disimpulkan bahwa Dosen menyediakan materi secara baik secara daring sehingga membuat mudah dimengerti mempunyai ratarata $84 \%$ berada pada kategori baik. 


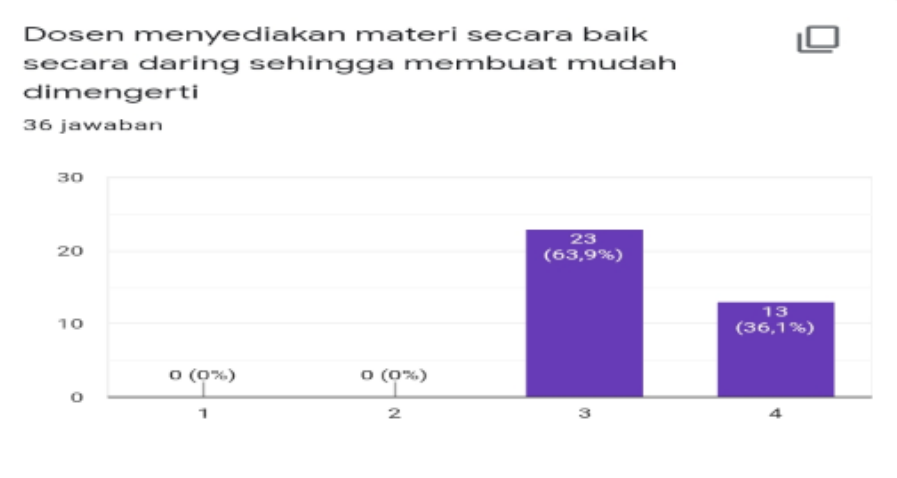

Gambar 4. Dosen menyediakan materi secara baik secara daring sehingga membuat mudah dimengerti

Dosen memberikan tugas yang relevan dengan materi ajar dan tujuan pembelajaran pada pembelajaran daring tergambar pada Gambar 5 berikut.

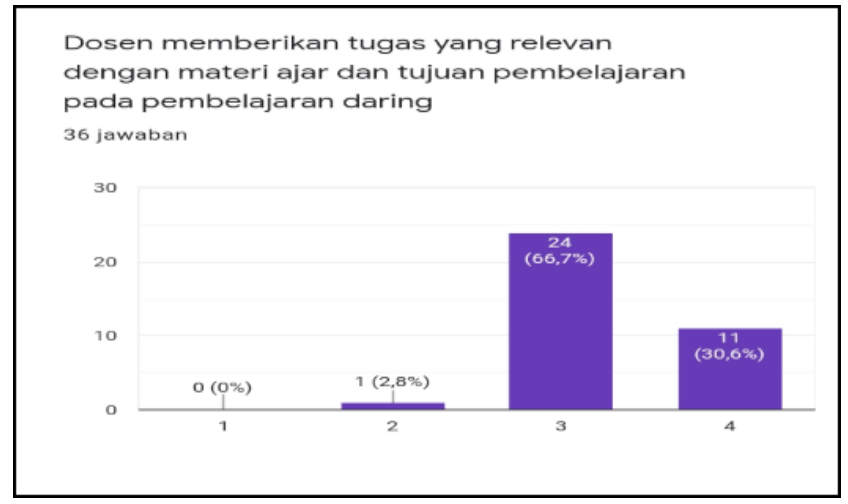

\section{Gambar 5. Dosen Memberikan Tugas yang Relevan dengan Materi Ajar dan} Tujuan Pembelajaran pada Pembelajaran Daring

Berdasarkan Gambar 5 terlihat bahwa Dosen memberikan tugas yang relevan dengan materi ajar dan tujuan pembelajaran pada pe mbelajaran daring dengan kriteria baik berada pada persentase $66,7 \%$ dan kriteria sangat baik dengan persentase $30,6 \%$ serta kurang baik dengan persentase $2,8 \%$. Sehinggadapat disimpulkan bahwa Dosen memberikan tugas yang relevan dengan materi ajar dan tujuan pembelajaran pada pembelajaran daring berada pada kriteria baik dengan rata-rata persentase $82 \%$. Penjelasan di atas dapat disimpulkan bahwa materi perkuliahan berada pada persentase $85,5 \%$ dengan kriteria sangat baik. Hal ini didukung oleh Widiyono yang menyatakan bahwa pembelajaran daring tidak akan dapat berjalan dengan baik dari segi pemahanan jika tugasyang diberikan kepada mahasiswa terlalu banyak dan tidak relevan. 
b. Aspek Penyampaian Materi

Dosen selalu memberikan penjelasan mengenai materi perkuliahan ketika belajar secara daring berada pada kriteria sangat baik dengan persentase $85,5 \%$. Hal ini tergambar pada Gambar 6 berikut.

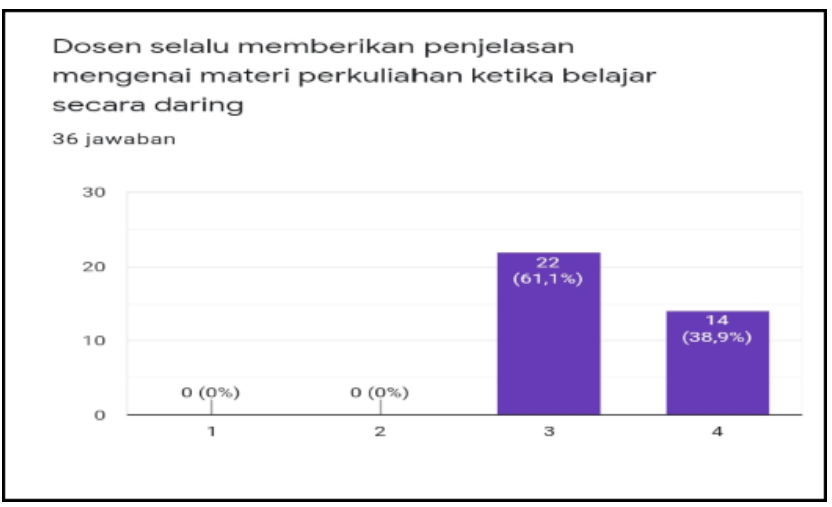

Gambar 6. Dosen selalu memberikan penjelasan mengenai materi perkuliahan ketika belajar secara daring

Berdasarkan Gambar 6 dapat dilihat bahwa dosen selalu memberikan penjelasan mengenai materi perkuliahan ketika belajar secara daring berada pada persentase $61,1 \%$ dengan kriteria baik dan kriteria sangat baik dengan persentase 38,9\%.

Perkuliahan dengan daring memudahkan dalam memahami materi perkuliahan tergambar pada Gambar 7 berikut.

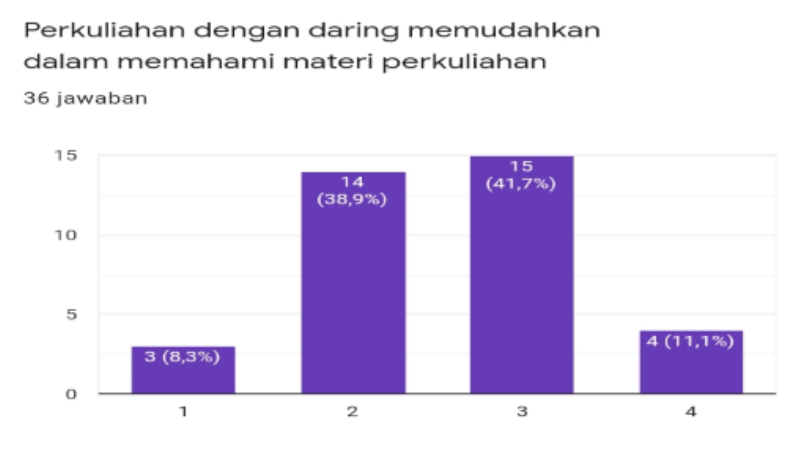

\section{Gambar 6. Perkuliahan dengan daring memudahkan dalam memahami materi perkuliahan}

Berdasarkan Gambar 7 dapat dilihat bahwa Perkuliahan dengan daring memudahkan dalam memahami materi perkuliahan berada pada persentase $8,3 \%$ dengan kriteria tidak baik, persentase $38,8 \%$ berada pada kriteriakurang baik, persentase $41,7 \%$ berada kriteria baik dan kriteria sangat baik dengan persentase $11,1 \%$. Hal ini didukung oleh pernyataan damayanti bahwa mahasiawa tidak mampu memahami prosespembelajaran hanya dengan mendengar dan menerima 
apa yang disampaikan dosen, perlu adanya proses mencari, menemukan dan menyimpulkan apa yang akan dipelajari secara mandiri.

Dosen menjelaskan pertanyaan yang diajukan oleh mahasiswa ketika belajar secara daring terdapat pada Gambar 8 berikut.

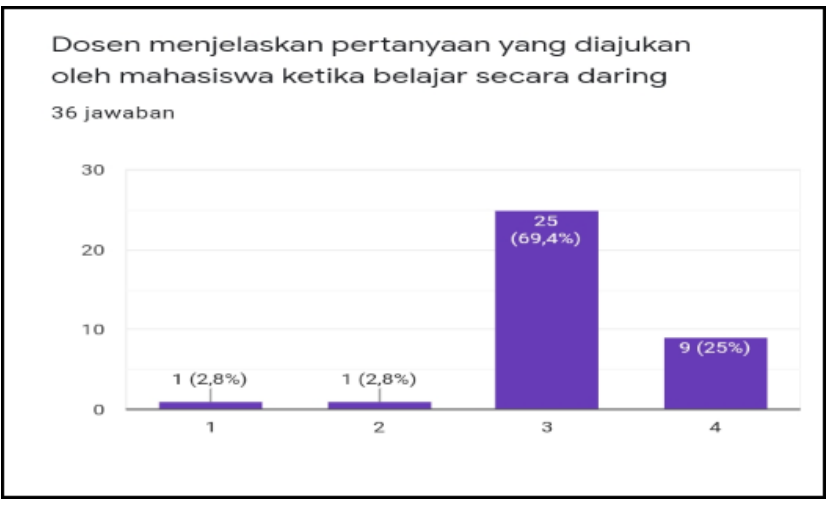

Gambar 8. Dosen menjelaskan pertanyaan yang diajukan oleh mahasiswa ketika belajar secara daring

Berdasarkan Gambar 8. dosen menjelaskan pertanyaan yang diajukan oleh mahasiswa ketika belajar secara daring berada pada kriteria sangat baik dengan persentase $25 \%$, kriteria baik dengan persentase 69,4\%, kriteria kurang baik dengan persentase 2,8\% dan kriteria tidak baik dengan kriteria 2,8\%.

Dosen mendorong mahasiswa untuk aktif di kelas (contoh: bertanya, diskusi) secara daring terdapat pada Gambar 9 berikut.

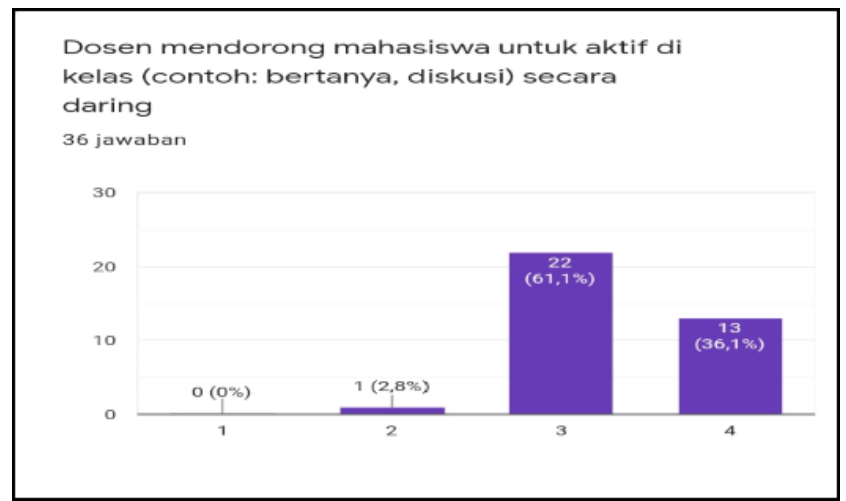

\section{Gambar 9. Dosen mendorong mahasiswa untuk aktif di kelas (contoh: bertanya, diskusi) secara daring}

Berdasarkan Gambar 9 terlihat bahwa dosen mendorong mahasiswa untuk aktif di kelas (contoh: bertanya, diskusi) secara daring berada pada kriteria sangat baik dengan persentase $36,1 \%$, kriteria baik dengan persentase $61,1 \%$, dan kriteria kurang baik dengan persentase $2,8 \%$. Penjelasan di atas dapat disimpulkan bahwa Penyampaian Materi berada pada persentase 79,5\% dengan kriteria baik. 
c. Aspek Pengelolaan Kelas

Perkuliahan secara daring dilaksanakan tepat waktu terlihat pada Gambar 10 berikut.

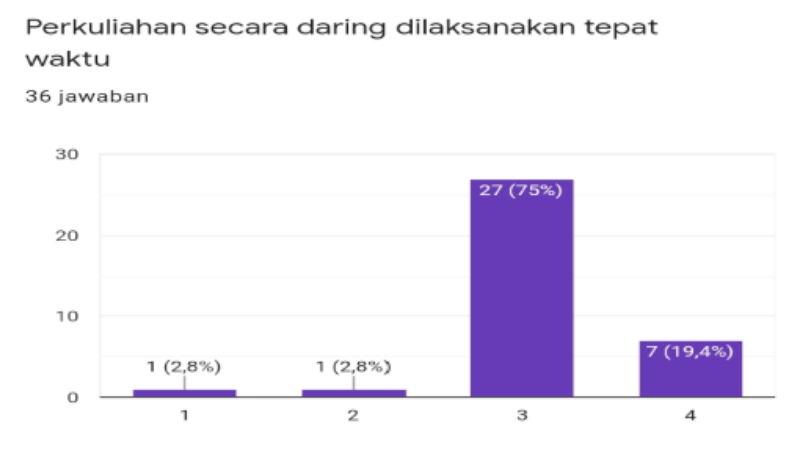

Gambar 10. Perkuliahan secara daring dilaksanakan tepat waktu

Berdasarkan Gambar 10. Terlihat bahwa Perkuliahan secara daring dilaksanakan tepat waktu berada pada kriteria sangat baik dengan persentase 19,4\%, kriteriabaik dengan persentase $75 \%$, kriteria kurang baik dengan persentase $2,8 \%$ dan kriteriatidak baik dengan persentase $2,8 \%$.

Dosen selalu membimbing dalam perkuliahan dengan metode daring sehingga membuat lebih paham terhadap materi perkuliahan terdapat pada Gabar 11. Berikut.

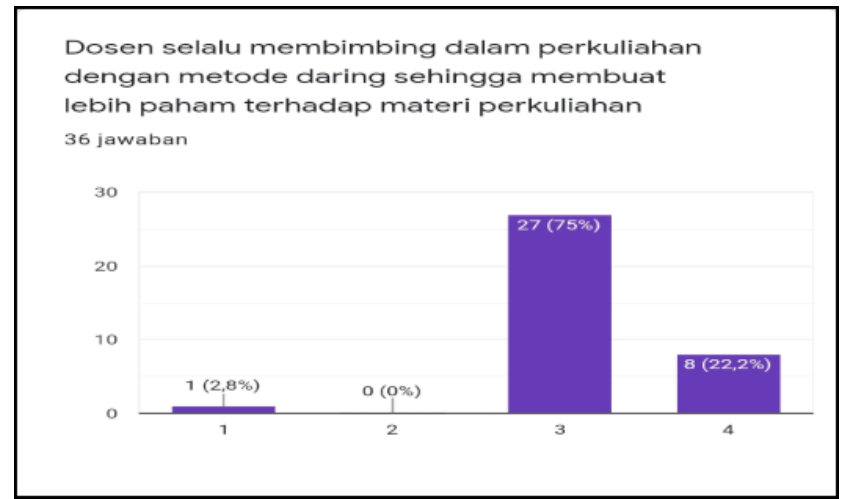

\section{Gambar 11. Dosen selalu membimbing dalam perkuliahan dengan metode daring sehingga membuat lebih paham terhadap materi perkuliahan}

Berdasarkan Gambar 11 berikut terlihat bahwa Dosen selalu membimbing dalam perkuliahan dengan metode daring sehingga membuat lebih paham terhadap materi perkuliahan berada pada kriteria sangat baik dengan persentase $22,2 \%$, kriteria baik dengan persentase $85 \%$ dan kriteria tidak baik dengan persentase 2,8\%. Halini didukung oleh hasil penelitian Putri yang menunjukkan sebagian mahasiswa merasa sulit untuk memahami pembelajaran secara daring. 
Sikap dosen yang terbuka terhadap masukan/kritikan untuk memperbaiki mutu pembelajaran daring tertuang pada Gambar 12 berikut.

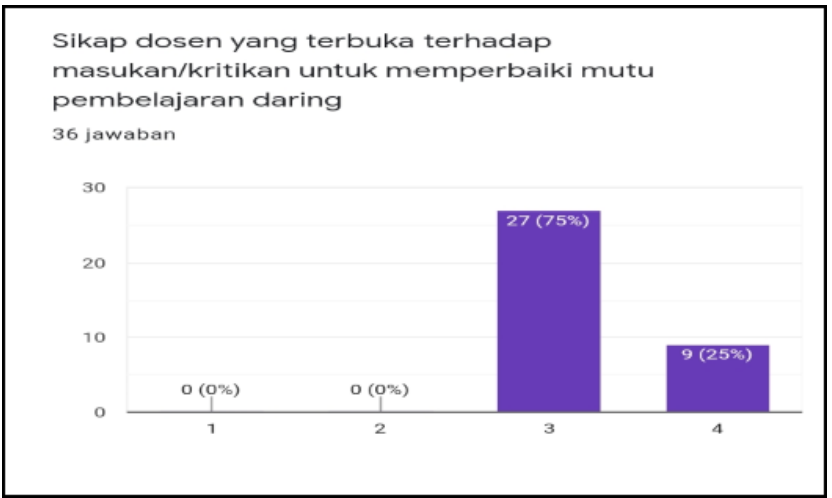

\section{Gambar 12. Sikap dosen yang terbuka terhadap masukan/kritikan untuk memperbaiki mutu pembelajaran daring tertuang}

Berdasarkan Gambar 12. Terlihat bahwa Sikap dosen yang terbuka terhadap masukan/kritikan untuk memperbaiki mutu pembelajaran daring berada pada persentase $25 \%$ dengan kriteria sangat baik dan persentase $75 \%$ dengan kriteria baik.

Dosen membantu kesulitan mahasiswa dalam materi ajar yang dipelajari terlihat pada Gambar 13 berikut.

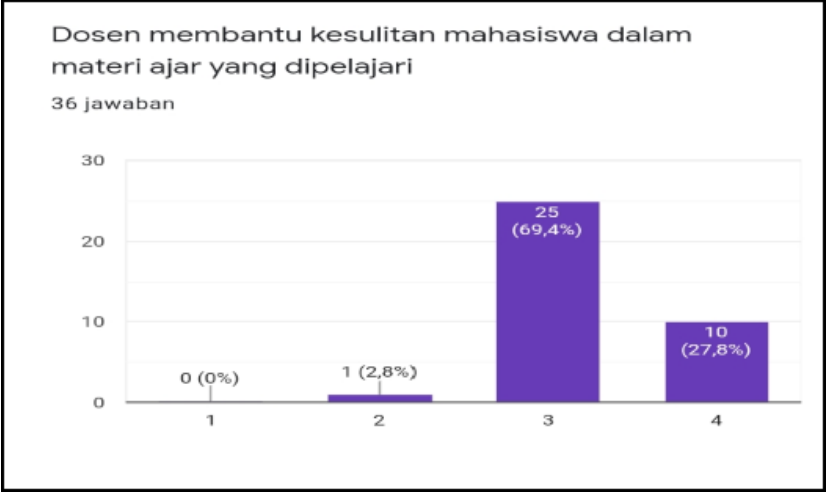

\section{Gambar 13. Dosen membantu kesulitan mahasiswa dalam materi ajar yang dipelajari}

Berdasarkan Gambar 13. Terlihat bahwa Dosen membantu kesulitan mahasiswa dalam materi ajar yang dipelajari berada pada kriteria sangat baik dengan persentase $27,8 \%$ dan kriteria baik dengan persentase $69,4 \%$ serta kriteria kurang baik. Penjelasan di atas dapat disimpulkan bahwa pengelolaan Kelas berada pada persentase $79,5 \%$ dengan kriteria baik.

d. Aspek Evaluasi Pengajaran 
Pembelajaran daring sangat membantu dalam menggantikan pembelajaran secara tatap muka di masa pandemi covid 19 dapat digambarkan pada Gambar 14 berikut.

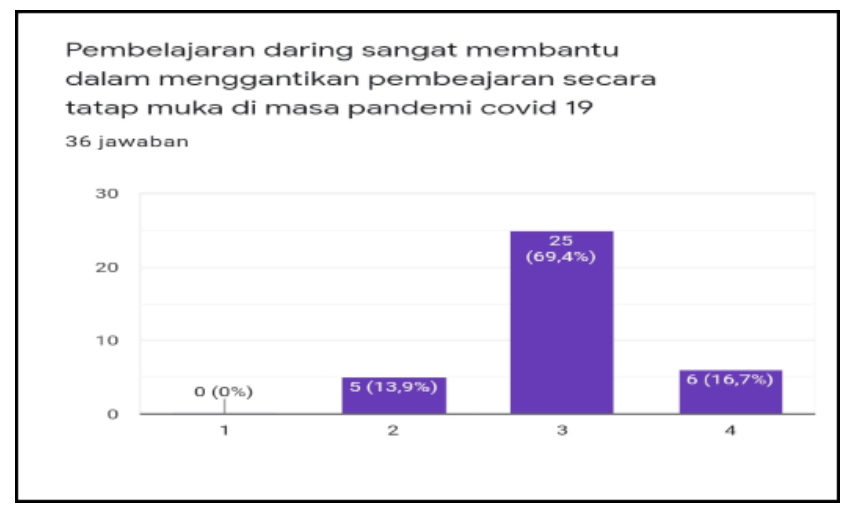

\section{Gambar 14. Pembelajaran daring sangat membantu dalam menggantikan pembeajaran secara tatap muka di masa pandemi covid 19}

Berdasarkan Gambar 14. Terlihat bahwa pembelajaran daring sangat membantu dalam menggantikan pembelajaran secara tatap muka di masa pandemi covid 19 dengan persentase $16,7 \%$ pada kriteria sangat baik, persentase $69,4 \%$ pada kriteria bak dan $13,9 \%$ pada kriteria kurang baik.

Perkuliahan dengan daring solusi belajar untuk menggantikan perkuliahan tatap muka dapat digambarkan pada Gambar 15. berikut.

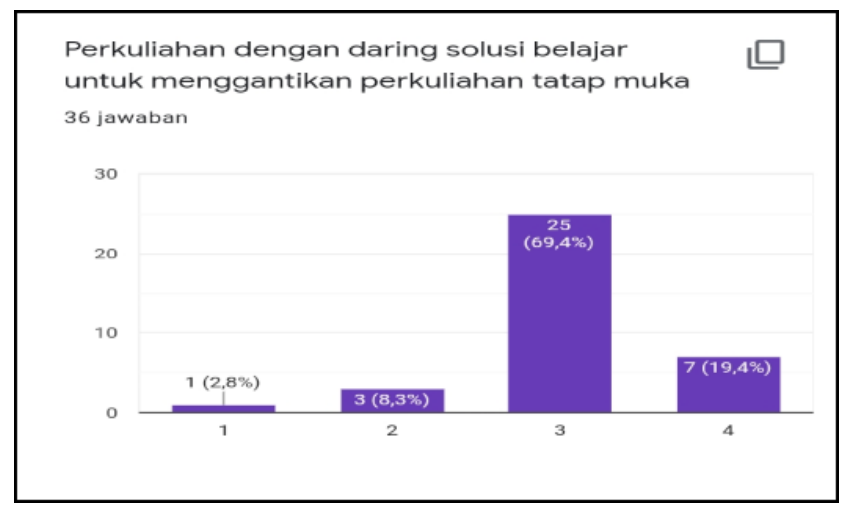

\section{Gambar. 15. Perkuliahan dengan daring solusi belajar untuk menggantikan perkuliahan tatap muka}

Berdasarkan Gambar 15, Perkuliahan dengan daring solusi belajar untuk menggantikan perkuliahan tatap muka berada pada persentase 19,4\% dengan kriteria sangat baik, persentase 69,4 pada kriteria baik, persentase 8,3 pada kriteria kurang baik dan persentase 2,8 dengan kriteria tidak baik. Hal ini didukung oleh Pratiwi, yang menyatakan bahwa pembelajaran daring pada masa covid-19 adalah solusi yeng membantu proses pembelajaran. 
Pembelajaran dengan daring dapat dengan mudah diakses dimana saja digambarkan pada Gambar 16 berikut.

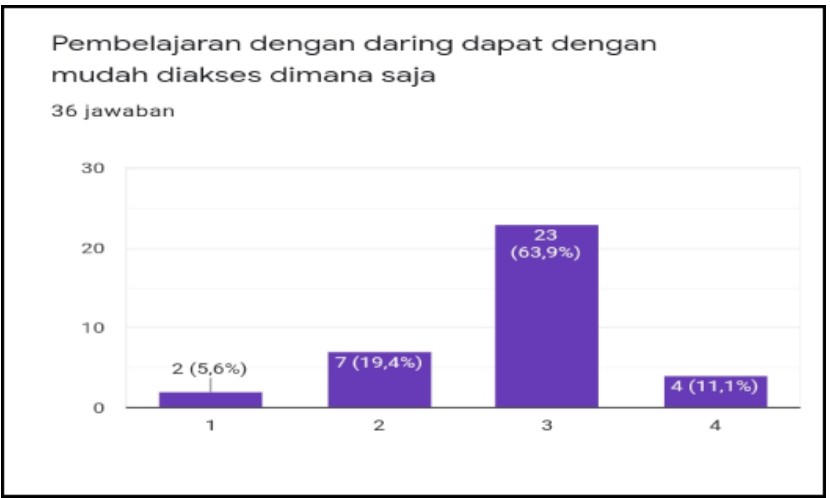

Gambar 16. Pembelajaran dengan daring dapat dengan mudah diakses dimana saja

Berdasarkan Gambar 16, terlihat bahwa pembelajaran dengan daring dapat dengan mudah diakses dimana saja memiliki persentase $11,1 \%$ dengan kriteria sangat baik, persentase $63,9 \%$ dengan kriteria baik, persentase $19,4 \%$ dengan kriteria kurang baik dan persentase 5,6\% dengan kriteria tidak baik.

Perkuliahan dengan daring dapat mempermudah dalam mengirim tugas tepat waktu tergambar pada Gambar 17 berikut.

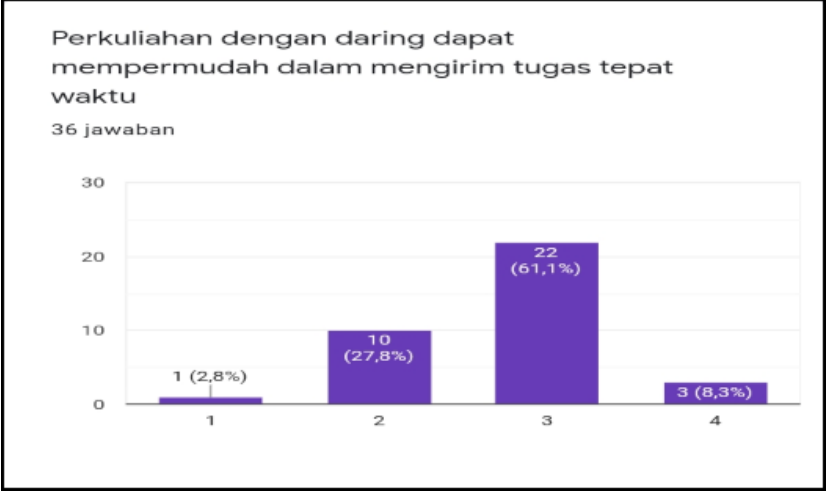

\section{Gambar 17. Perkuliahan dengan daring dapat mempermudah dalam mengirim tugas tepat waktu}

Berdasarkan Gambar 17, terlihat bahwa Perkuliahan dengan daring dapat mempermudah dalam mengirim tugas tepat waktu berada pada persentase $8,3 \%$ dengan kriteria sangat baik, pada kriteria baik dengan persentase $61,1 \%$, pada kriteria kurang baik dengan persentase $27,8 \%$ dan apada kriteria kurang baik dengan persentase $2,8 \%$.

Penjelasan di atas dapat disimpulkan evaluasi pengajaran berada pada kriteria baik dengan persentase $72,25 \%$, hal ini sejalan dengan penrnyataan Damayanti dalam penelitiannya bahwa seharusnya pembelajaran online seharusnya memberikan 
kebebasan kepada mahasiswa untuk mengembangkan kemampuannya untuk mengevaluasi diri sendiri.

Analisi angket terbuka menunjukkan bahwa kesulitan mahasiswa dalam pembelajaran daring diantaranya koneksi internet yang masih kurang stabil, jaringan yang sulit di daerah perdesaan tempat mereka tinggal. terbatasnya kuota internet, kurang kefokusan mahasiswa dalam belajar daring karenaperkuliahan dilakukan bersamaan dengan pekerjaan rumah. Sementara itu kelebihan pembelajaran daring adalah bisa menggunakan berbagai media pembelajaran, pembelajaran dapat dilaksanakan dimana saja.tidak mengeluarkan biaya untuk pergi ke kampus, memudahkan mahasiswa dalam menyerahkan tugas, pembelajarandapat melatih keahlian dibidang teknologi sehingga mahasiswa dituntu untuk lebih kreatif.

\section{KESIMPULAN}

Berdasarkan pada hasil analisis data penelitian yang telah diuraikan, maka dapat disimpulkan persepsi mahasiswa terhadap pembelajaran daring sebagai berikut.

1. Indikator materi perkuliahan rata-rata 3,42 dengan persentse $85,5 \%$ berada pada kriteria sangat baik.

2. Indikator penyampaian materi rata-rata 3,11 dengan persentse $77,75 \%$ berada pada kriteria baik.

3. Indikator pengelolaan kelas rata-rata 3,18 dengan persentse $79,5 \%$ berada pada kriteria baik.

4. Indikator evaluasi pengajaran rata-rata 2,89 dengan persentse $75,75 \%$ berada pada kriteria baik.

\section{REFERENSI}

Aan Widiyono . 2020. Efektifitas Perkuliahan Daring (Online) Pada Mahasiswa PGSD di saat Pandemi Covid-19, Jurnal Pendidikan, Vol.8, No.2

Agus Sujanto. 1986. Psikologi Umum. Jakarta: Aksara Baru.

Alo Liliweri. 1994. Persepsi Teoritis. Bandung: Cipta Aditya Bakti.

Arikunto. 2010. Prosedur Penelitian: Suatu Pendekatan Praktik. Jakarta: Rineka Cipta.

Edno Kamelta. 2013. Pemanfaatan Internet oleh Mahasiswa Jurusan Teknik Sipil Fakultas Teknik Universitas Negeri Padang, Jurnal UNP, Vol. 1, No. 2, (2013).

Hutomo Atman Maulana. 2020. Persepsi Mahasiswa terhadap Pembelajaran Daring pada Mata Kuliah Praktik di Pendidikan Vokasi. Jurnal Pendidikan, Vol.8, No.2, (2020). 
Mohammad Asrori. 2009. Psikologi Pembelajaran. Bandung: CV Wacana Prima.

Sri Widayanti. 2020. Persepsi Mahasiswa pada Proses Pembelajaran Mata Kuliah Daring. Child Education Journal. Vol.2. No.2.

Trianto. 2011. Mendesain Model Pembelajaran Inovatif-Progresif. Jakarta: Kencana.

Wariyah, dkk. 2014. Lembaga Penelitian dan Pengabdian Kepada Masyarakat Universitas Mercu Buana Yogyakarta. Jurnal Sosio-Humaniora. Vol.5.No. 4. 